\title{
Attitude and Motivation of Engineering Students' towards Participating in Student-Centered Learning Activities
}

\author{
Norsuhaidah Mohamad*, Alias Masek, Zawani Zawawi, Fatin Syazwani Mohd Zuki \\ Faculty of Technical and Vocational Education, Universiti Tun Hussien Onn Malaysia, Malaysia
}

Received June 10, 2020; Revised July 21, 2020; Accepted August 25, 2020

\section{Cite This Paper in the following Citation Styles}

(a): [1] Norsuhaidah Mohamad, Alias Masek, Zawani Zawawi, Fatin Syazwani Mohd Zuki, "Attitude and Motivation of Engineering Students' towards Participating in Student-Centered Learning Activities, "Universal Journal of Educational Research, Vol. 8, No. 9, pp. 4325-4332, 2020. DOI: 10.13189/ujer.2020.080959.

(b): Norsuhaidah Mohamad, Alias Masek, Zawani Zawawi, Fatin Syazwani Mohd Zuki (2020). Attitude and Motivation of Engineering Students' towards Participating in Student-Centered Learning Activities. Universal Journal of Educational Research, 8(9), 4325-4332. DOI: 10.13189/ujer.2020.080959.

Copyright $(2020$ by authors, all rights reserved. Authors agree that this article remains permanently open access under the terms of the Creative Commons Attribution License 4.0 International License

\begin{abstract}
Students' active participation in-class activities such as group discussion, problem-solving and making decision might be associated with several predictors including previous experiences, knowledge, confidence, and gender. The purpose of this study was identifying the attitudes and motivation level towards student-centred learning approaches, including analysis based on gender. The sample is comprised of 299 engineering students (civil, electrical and mechanical engineering) from one of the higher education institutions in southern of peninsular of Malaysia. The instrument, a set of questionnaire comprised of three parts was used to collect the data; namely, part A demographic information, part B students attitude toward student centred learning, and part C, students motivation toward learning in students centred learning. The data were analysed using frequency, mean score, and standard deviation, as well as t-test. The result indicated a high score on attitude $(\mathrm{M}=3.95 ; \mathrm{SD}=0.49)$ and motivation ( $\mathrm{M}=4.16 ; \mathrm{SD}=0.46)$ level in participating in student-centred learning activities. Also, there is no significant difference between gender for students' attitude and motivation to participate in student-centred learning activities. The implication is that student-centred learning activity implementation can be designed to emphasize on attitude and motivation factors, without considering gender factor to achieve active participation and effective learning.
\end{abstract}

Keywords Attitude, Motivation, Student-centered Learning, Gender, Higher Education Students

\section{Introduction}

Learning effectiveness is associated with many predictors, including teaching and learning approaches, especially on students' attitude and motivation. Integrating several different methods of teaching and learning for a class session are important since they could affect students' motivation (Hsia \& Sung, 2019). Nowadays, the education system has been tremendously changing towards student-centred learning (Mahamod \& Lambri, 2015). Teacher-centred approach has now become the second choice, especially within the capacity to build a workforce to meet industrial needs. In line with the industrial revolution 4.0, students' active participation in learning seems vital to develop their own competency on particular skills, and it is also in line with the government's initiatives to emphasize on technical and vocational education training (TVET). This training aims to produce engineering students' capacity to build their own technical expertise, critical thinking, and good communication skills that bring real-world learning opportunities into the classroom as a pedagogical approach, which has the potential to enhance the development of students' generic skills (Pavlova \& Chen, 2019).

The student-centred learning approach is defined as a method of learning, where students play their main role in 
the learning session, and typically they need to solve problems in a group setting, provided by facilitators (Ismail, 2015). It is believed that this approach can effectively encourage students' engagement and active participation, especially in the capacity to enhance students' independent thinking, knowledge and skills, and eventually improves critical thinking (Kornell \& Bjork, 2007). The implementation of student-centered learning requires mediation tools such as collaborative learning, cooperative learning, problem-based learning, small group learning, and project-based learning. It can also be conducted in a group discussion form, case-study, think-pair-share, debate, presentation, and self-directed learning (Al-Balushi, 2020). These activities can also be embedded in problem-based learning, e-learning, project-based learning, computer-based learning, and cooperative learning (Ismail, 2015). Based on these premise, previous studies have favored on student-centred learning to have more benefit than the traditional teaching curriculum (Baetan et al, 2013), especially in improving students' skills. Given with more opportunities to gain experiences in active learning, students can solve the problems by activating their critical and creative thinking, within the cooperative learning environment between group members (Iberahim, Mahamod, \& Mohamad, 2017). In Ismail and Awang (2004), students' indicated improvement in attitudes towards computerized and internet-based cooperative learning approaches for a slow learner. Student performed better on project-based learning with other group members and positively growing in their self-esteem and desire to learn.

Students-centred learning environment was the key factor for the success of student-centred learning activities (Yahaya et al., 2011). Students will be able to build their understanding through resources that have been prepared by their facilitator and complete their assignments through cooperative and collaborative learning in classes. The uses of appropriate learning materials with creative elements and a comfortable classroom environment during teaching class could influence the students' development of knowledge, skills, and behaviour; but teachers must be willing to accept students' progress and develop appropriate teaching strategies for learning enforcement (Hashim et al., 2019). It is within this capacity; the students are expected to build their positive attitude and motivation towards learning compared to teacher centred learning in a traditional classroom setting.

Student-centred learning approach activates students in the classroom. According to Nawi, Zakaria and Hashim (2017), students are highly motivated to involve in a discussion session together among group members, cooperate, and develop team spirit and self-confidence in problem-solving activities. In a study by Li (2016), using student-centred learning activities has a positive impact on students attitude and motivation, where students were more excited when the context used in the module has a unique animation and graphic elements based on what they previously has taught. In fact, this interactive learning can also make students be more proficient, creative and critical in thinking.

In regards to students' gender, previous studies suggest that enhancing student motivation does not associate to the gender of the individual, but it depends on the methods used in student-centred learning that will provide greater motivation, enthusiasm, and effort to learn. This has proven in the study from Tasgin and Coskun (2018), which highlights that environmental factors in the classroom influence students' motivation instead of gender on students' level of motivation towards achievement in their learning. This can be justified based on the other study's finding, whereby student-centred learning not only positively impact student's achievement, but it also positively impacts the social relations between classmates and cooperating in discussions (Somasundram \& Mahamod, 2017).

However, there has been a skeptical issue pertinent to some of engineering students of their active participation in a group discussion, due to several factors including their thinking style, personal, contextual, gender factors, and family background (Han, Sax \& Kim, 2007; Remedious, Clarke \& Hawthorne, 2008; Abdullah, Abu Bakar \& Mahbob, 2012; Opie, Livingston, Greenberg, \& Murhpy, 2019), especially for Asian students (Remedious, Clarke \& Hawthorne, 2008; Leatemia, Susilo \& van Berkel, 2016). In addition, student-centred learning approaches that uses the discussion method are usually difficult to be applied when there is no guidance from the facilitator (Leatemia et al., 2016), which eventually affect students' attitude and motivation in learning. An absence of the facilitator's role might be the main reasons; particularly when students received less encouragement and guidance. Thus, students were facing difficulty in completing their task with their own abilities. On the other hands, students' involvement in a student-centred learning approach is still not encouraging because of lack of understanding in their role (Pentawar, 2020), leading to a failure in achieving the main goal of student-centred learning implementation. In the worst case, some graduated students might have difficulty to perform in their work field, due to lack of technical expertise, soft skill, and also communication skills (Ting et al., 2017; Ali, 2019). In the study from Ibrahim, et al. (2012), students still do not know how to use information technology and communication equipment, due to the teachers who do not play their role in providing appropriate guidance to engineering students on how to use computer for learning. Therefore, this study was to identify students' attitude and motivation level towards student-centred learning approaches. The specific research questions were formulated as follows:

(i) What is the engineering students' attitude toward student-centred learning activities? 
(ii) What is the engineering students' motivation level in participating in student-centred learning activities?

(iii) Is there a significant difference between male and female of engineering students' attitude toward student-centred learning activities?

(iv) Is there a significant difference between male and female of engineering students' level of motivation toward student-centred learning activities?

\section{Methodology}

A descriptive quantitative survey study was conducted using questionnaire, to gauge students' motivation and attitude towards students-centred learning activities such as group discussion, problem-solving and making decision activities within groupwork. According to Timbang, Mahamod, Yusoff and Badushah (2010), this design involves the procedure of collecting and processing data based on planning that that could be specific and systematic where it involves the variables of the study.

\subsection{Participants}

A convenience sampling was conducted that involved 302 out of 1396 engineering students, comprised of a total of 156 males and 146 females from one of higher educational institutions in Northern Peninsular of Malaysia. The subjects were amongst the first year to the final year students who enrolled in their first degree programme in the 2018/2019 academic session.

\subsection{Measures}

In this research, a set of questionnaires were used to collect the data, which consists of three major parts.

a) Part A: form with personal and professional data (gender and course of study)

b) Part B: comprises of 15 items to gauge students' attitude towards student-centred learning activities adapted from Amedu and Gudi (2017), reliability index using alpha Cronbach was 0.90. Items were rated based on five-points likert scale (highly agreed, agreed, modest, disagree and highly disagree), where the respondent can have the most appropriate answer according to their agreement on the statement. The likert scale was chosen as it is appropriate to indicate psychological trait and to obtain data on a person's situation against an issue or conclusion, in the form of an opinion measurement (Budiaji, 2013).

c) Part C: comprises of 12 items to gauge students' motivation level towards student-centred learning activities adapted from Labeeb, Rajith, Ibrahim, and Kamal (2017), with reliability index 0.847 .

\subsection{Procedures}

Before conducting a study at the selected venue, permission was first requested to conduct the study from the faculty. Data were collected by face to face to but within the voluntarily basis. The respondent is not allowed to bring back the questionnaire to avoid any dropouts. A total of 380 copies were distributed to three faculties; however, only 329 questionnaires were returned and 30 of it were incomplete questionnaires. Thus, only 299 set of completed questionnaire were analysed.

\subsection{Data Analysis}

The statistical data used in this research were the mean score, standard deviation, and also independent t-test. In this research, there were four research questions that were analysed. Mean score and standard deviation descriptive methods were used for research question 1 and 2 . Meanwhile, an independent t-test was used to analyse the research question 3 and 4 .

\section{Results and Discussion}

Based on the data analysis, almost equivalent number of samples were managed to be collected from each faculty. Out of 299 complete questionnaires, a total of 85 respondents (45 males and 39 females) were from the Faculty of Civil and Environmental Engineering, 103 respondents (63 males and 49 females) from the Faculty of Electric and Electronic, and 112 respondents (48 males and 55 females) were from the Faculty of Mechanical and Manufacturing Engineering. Data were almost equally distributed from each faculty.

\section{Engineering Students' Attitude towards student-centered Learning activities}

An analysis according to research questions were performed and presented in the next sections. Based on the finding, the student-centred learning approach was accepted by engineering students, where the overall mean score is at a high-level, indicating students have a positive attitude toward students centred learning activities. Items were shown in the Table 1.

An insight into specific analysis, the highest item mean score goes for item number 15 (more able to socialize with a classmate), with the value $\mathrm{M}=4.30, \mathrm{SD}=0.636$. The second highest item number 14 (able to enhance good relationship between classmate) that is $\mathrm{M}=4.24, \mathrm{SD}=$ 0.656. The data show that engineering students are cooperative with each other in class. According to social constructivism theory, students will normally interact with each other to build new knowledge and solve problems in the group. Table 1 shows the mean score and standard deviation for each item in the attitude variable.

\section{Engineering Students' Motivation towards student-centered Learning activities}

Based on findings, the results showed that the overall mean score for students' motivation level toward 
student-centred learning activities is at a high level, as shown in the Table 2. The highest mean score goes for item number 1 (I feel good when the group task was solved) with the mean score value at $\mathrm{M}=4.40, \mathrm{SD}=0.684$ and the second-highest mean score is for item number 3 (I am very interested in a study using student-centred learning approach) with $\mathrm{M}=4.38, \mathrm{SD}=0.507$. These findings indicated that engineering students enjoyed, attracted and committed to participate in student-centred learning activities such as group discussion, presentation and debate. This might be stimulated by several encouraging elements in a student centred learning setting; for example, the enjoyment of solving the challenging task, cognitive conflict, and a positive interaction with facilitator.

Table 1. Mean score for students' attitude towards student centred learning activities

\begin{tabular}{|c|c|c|c|c|}
\hline \multirow[t]{2}{*}{ Item } & Statement & \multirow[t]{2}{*}{ Mean Score } & \multirow{2}{*}{$\begin{array}{l}\text { Standard } \\
\text { Deviation }\end{array}$} & \multirow{2}{*}{$\begin{array}{l}\text { Interpretation of } \\
\text { Attitude }\end{array}$} \\
\hline & Student-Centered Learning Approach: & & & \\
\hline 1 & I enjoy study using this method & 3.95 & 0.684 & High \\
\hline 2 & I feel easy to use this method in the classroom & 3.96 & 0.653 & High \\
\hline 3 & I always focus during my study group & 3.81 & 0.815 & High \\
\hline 4 & $\begin{array}{c}\text { I give cooperation with my study group member } \\
\text { during our discussion }\end{array}$ & 4.10 & 0.720 & High \\
\hline 5 & $\begin{array}{l}\text { I share my idea and information with my study } \\
\text { group members }\end{array}$ & 4.14 & 0.683 & High \\
\hline 6 & $\begin{array}{l}\text { I enjoy can involve in all learning activities with } \\
\text { my classmates }\end{array}$ & 4.09 & 0.754 & High \\
\hline 7 & I am more interested to learn & 3.92 & 0.815 & High \\
\hline 8 & I enjoy attend the class & 3.84 & 0.783 & High \\
\hline 9 & $\begin{array}{l}\text { I willing to participate all learning activities in } \\
\text { class }\end{array}$ & 3.95 & 0.818 & High \\
\hline 10 & $\begin{array}{l}\text { I like to find more information before attend the } \\
\text { class }\end{array}$ & 3.47 & 0.969 & High \\
\hline 11 & $\begin{array}{l}\text { I like to voice out my opinion in any discussion } \\
\text { activities }\end{array}$ & 3.87 & 0.828 & High \\
\hline 12 & I can stimulate my critical thinking in my study & 4.07 & 0.672 & High \\
\hline 13 & I get opportunity to think and give my opinion & 4.11 & 0.647 & High \\
\hline 14 & $\begin{array}{l}\text { I can improve the better relationship among my } \\
\text { classroom }\end{array}$ & 4.24 & 0.656 & High \\
\hline 15 & I can more socialize with my classmates & 4.30 & 0.636 & High \\
\hline \multicolumn{2}{|r|}{ Total } & 3.95 & 0.485 & High \\
\hline
\end{tabular}

Table 2. Mean score for students' motivation level towards student centred learning activities

\begin{tabular}{|c|c|c|c|c|}
\hline Item & Statement & Mean Score & Standard Deviation & $\begin{array}{c}\text { Interpretation of } \\
\text { Motivation }\end{array}$ \\
\hline 1 & I feel good when the group task was solved & 4.40 & 0.684 & High \\
\hline 2 & $\begin{array}{l}\text { I become more positive in class either } \\
\text { faced difficult situation }\end{array}$ & 4.10 & 0.764 & High \\
\hline 3 & $\begin{array}{l}\text { I am very interested in study using student } \\
\text { centered learning approach }\end{array}$ & 4.38 & 0.507 & High \\
\hline 4 & $\begin{array}{l}\text { I think student centered learning approach } \\
\text { is relevant with my study }\end{array}$ & 3.98 & 0.771 & High \\
\hline 5 & $\begin{array}{l}\text { I become more excited to learn through } \\
\text { discussion }\end{array}$ & 4.02 & 0.736 & High \\
\hline 6 & $\begin{array}{l}\text { I like to give my idea while having a group } \\
\text { discussion }\end{array}$ & 3.99 & 0.724 & High \\
\hline 7 & $\begin{array}{l}\text { I feel like to learn more when get reward } \\
\text { and praise }\end{array}$ & 3.88 & 0.953 & High \\
\hline 8 & $\begin{array}{c}\text { I will more excited to learn when the } \\
\text { situation and have good surrounding in my } \\
\text { classroom }\end{array}$ & 4.26 & 0.684 & High \\
\hline 9 & $\begin{array}{l}\text { I feel easy to do some activities when there } \\
\text { is cooperation between my classmates }\end{array}$ & 4.31 & 0.649 & High \\
\hline 10 & $\begin{array}{l}\text { I like to discuss with my study group } \\
\text { members during discussion session }\end{array}$ & 4.14 & 0.761 & High \\
\hline 11 & $\begin{array}{l}\text { I feel easy to cooperate with my group } \\
\text { members to solve the group task }\end{array}$ & 4.26 & 0.658 & High \\
\hline \multicolumn{2}{|r|}{ Total } & 4.16 & 0.455 & High \\
\hline
\end{tabular}




\section{A comparison of students' attitude between genders}

Data analysis was performed using an independent t-test, to compare students' attitude towards student-centred learning between males and females. Based on Table 3, a descriptive analysis indicated by the mean score and standard deviation show that the mean score for female (M $=4.00, \mathrm{SD}=0.49)$ students is slightly higher than that of their male counterparts $(\mathrm{M}=3.97, \mathrm{SD}=0.48)$.

Table 3. Descriptive analysis of mean score Between Genders for students' Attitude

\begin{tabular}{|c|c|c|c|c|c|}
\hline \multicolumn{7}{|c|}{ Statistic Group } \\
\hline \multirow{3}{*}{ Attitude } & Gender & $\mathrm{N}$ & Mean & $\begin{array}{c}\text { Standard } \\
\text { Deviation }\end{array}$ & $\begin{array}{c}\text { Std. } \\
\text { Error } \\
\text { Mean }\end{array}$ \\
\cline { 2 - 6 } & Male & 156 & 3.97 & 0.47801 & 0.3852 \\
\cline { 2 - 6 } & Female & 146 & 4.00 & 0.49432 & 0.4105 \\
\hline
\end{tabular}

Further analysis using an independent t-test, the result shows that there is no significant difference between mean score of male and female students in attitude towards student centred learning [t $(297)=-0.539, \mathrm{p}>0.05]$. The details are presented in Table 4.

\section{A comparison of students' motivation between genders}

Next, data analysis was performed using an independent t-test to test if there is a significant difference of motivation level of engineering students between male and female towards student-centred learning. The descriptive analysis indicated that the male $(\mathrm{M}=4.17, \mathrm{SD}=0.47)$ students is slightly higher than that of the female $(\mathrm{M}=4.14, \mathrm{SD}=0.44)$ students towards student-centred learning activities. (See Table 5).

Further analysis using an independent t-test, similarly the result shows that there is no significant difference in the mean score of students' motivation level between male and female students towards students-centred learning activities [t $(297)=0.578, \mathrm{p}>0.05]$. (See Table 6).

Table 4 Independent t-test Result of Attitude

\begin{tabular}{|c|c|c|c|c|c|c|c|}
\hline \multicolumn{2}{|c}{} & \multicolumn{2}{|c|}{$\begin{array}{c}\text { Tevene's Test for equality } \\
\text { of variances }\end{array}$} & \multicolumn{5}{|c|}{ T-test of equality of score mean } \\
\cline { 3 - 8 } & F & Sig. & t & df & $\begin{array}{c}\text { Sig. } \\
(2 \text {-tailed) }\end{array}$ & $\begin{array}{c}\text { Mean } \\
\text { Difference }\end{array}$ & $\begin{array}{c}\text { Std. Error } \\
\text { Difference }\end{array}$ \\
\hline \multirow{2}{*}{ Attitude } & $\begin{array}{c}\text { Equal } \\
\text { variances } \\
\text { assumed }\end{array}$ & .916 & 0.339 & -0.539 & 297 & .590 & -.03031 \\
\hline
\end{tabular}

Table 5. Descriptive analysis of mean score Between Gender for students' motivation

\begin{tabular}{|c|c|c|c|c|c|}
\hline \multicolumn{7}{|c|}{ Statistic Group } \\
\hline \multirow{3}{*}{ Motivation } & Gender & N & Mean & Standard Deviation & Std. Error Mean \\
\cline { 2 - 6 } & Male & 156 & 4.17 & 0.47094 \\
\cline { 2 - 6 } & Female & 146 & 4.14 & 0.43859 \\
\hline
\end{tabular}

Table 6. An independent t-test Result of students' Motivation

\begin{tabular}{|c|c|c|c|c|c|c|c|c|}
\hline \multicolumn{9}{|c|}{ T-test } \\
\hline & & \multicolumn{2}{|c|}{$\begin{array}{l}\text { Levene's Test for } \\
\text { equality of variances }\end{array}$} & \multicolumn{5}{|c|}{ T-test of equality of score mean } \\
\hline & & $\mathrm{F}$ & Sig. & $\mathrm{t}$ & df & $\begin{array}{c}\text { Sig. } \\
\text { (2-tailed) }\end{array}$ & $\begin{array}{c}\text { Mean } \\
\text { Difference }\end{array}$ & $\begin{array}{l}\text { Std. Error } \\
\text { Difference }\end{array}$ \\
\hline Motivation & $\begin{array}{c}\text { Equal variances } \\
\text { assumed }\end{array}$ & .225 & .636 & .578 & 297 & .564 & .03047 & .05271 \\
\hline
\end{tabular}




\subsection{Discussion}

Students' active participation in class activities such as group discussion, problem-solving and making decision might be associated with several predictors, especially for engineering students including previous experiences, knowledge, confidence, and family background and gender factors. Therefore, this study initiated to identify students' attitudes and motivation level towards student-centred learning activities, at higher education institution. This study produces an encouraging finding, whereby students have positive attitude towards student-centred learning activities. This finding align with several previous studies; for instance, a study from Somasundram and Mahamod (2017), which found that a student-centred learning approach brings a positive effect on students' achievement and attitude, which is a good impact on their social life among their classmates. Murphy (2005) also proves this occurrence, where cooperative learning can be improved by the interaction between students. In previous research from Fadzilah (2017), the study also expresses that the successful of cooperative learning by involves students' making assignments together in the group. This cooperative learning approach will be achieved based on student achievement by cooperative group.

According to Ibrahim, Mahamod and Mohamad (2017), a student-centred learning approach gives advantages to lead more experiences in active learning to students for solve the problems through critical thinking, creative and cooperative learning between group members. Meanwhile, research from Ismail and Awang (2004) found that there is a previous research in Malaysia about cooperative learning approaches between problematic and good students to identify students' attitudes towards computerized and internet-based. The findings of the study showed that problematic students can find project information with other group members. This finding also shows that problematic students respond positively when they are in the cooperative learning group. Thus, they can increase their self-esteem and desire to learn. This statement supported by Yahaya et al. (2011), which stated that learning environment is one of the key factor in a student-centred learning approach to cooperative learning. For example, teaching aids with creative elements and comfortable classroom environment during teaching class.

Meanwhile, the results of study have shown that overall mean score level of motivation for engineering students towards student-centered learning at a higher level It shows that student-centred learning approached to the students involves an intrinsic and extrinsic motivation that can increase motivation level toward learning. The results of these findings are align with study of Abdullah, Md Sham and Ismail (2018), motivation occurs when there are stimuli and environmental influences that may cause a person's desire to do something seriously. It is proven by previous research by Abdullah, Md Sham dan Ismail (2018), motivation occurs when there are stimuli and environmental influences that may cause one's desire to do something vigorously. The strength of a person's motivation depends on experience, incentives or rewards given. Based on Abusama et al., (2017), students with a high level of motivation will show progressive action when receiving a reward, praise, and good grade. This statement can be attributed to higher mean score in the study where the level of students' attitudes towards learning such as students feel fun and easy when using a student-centered learning approach. When students' attitudes or behaviors show a positive effect on learning, then indirectly the level of student motivation also increases. Besides, motivation and attitude are related to each other which can be proven from a study by Prayekti (2016), that students with positive or negative motivation will determine their behaviour whether they will achieve the goal or not.

In addition, interest is also part of the motivation that can push someone to do whatever they want. Based on Chen, Masek, and Amiruddin (2014), if there are elements of interest in the students indirectly creating whole better learning where teaching methods and learning activities is way to arouse the interest of students. Findings in this study also show that students are eager to learn through discussion. This result shows the method used in a student-centred learning approach, which is a discussion method, can inspire students to motivate themselves. According to Masek (2016), an appropriate technique of facilitation should have stimulated students' motivation to learn and enable them to actively participate and take part in the group work during in student centred learning activities.

Furthermore, the result highlights that there is no difference in attitude level of engineering students between male and female towards student-centred learning. This means that engineering students between male and female possess the same behaviour towards learning. Hence, the student's gender does not influence learning attitudes in student-centred learning. The statement supported a study from Basir, Hamzah and Abdul Razak (2017), which mentions that there is no significant difference of attitude between male and female students towards problem-based learning, which is known as a student-centred learning approach. Hence, that students' attitude is driven by student-centred learning, for example, cooperative learning, self-learning, critical problem solving, and ability to solve the problem with creative, lead to increase the attitude student without effect by gender.

Besides, finding shows there is no difference in the motivation level of engineering students between male and female toward student-centred learning. It is because that spirit, initiative, and support towards student-centred learning does not depend on gender. This fact is also supported by Nasser and Hamza (2013), which states that students who are highly motivated because there is a strong and steady encouragement. This encouragement is a result 
of the stimulus, which includes awards, honors, marks, grades and so on. Therefore, it is concluded that the increase in student motivation does not depend on gender but the methods used in student-centered learning that give motivation, enthusiasm and initiative to learn more.

\section{Conclusions}

Student-centred learning approach gives a positive effect on engineering students as indicated by the findings, whereby a higher score on attitude and motivation level by participating in student-centred learning activities. Student-centered learning approach can encourage students to build more creative and critical thinking, students can solve problems in groups, seek and share ideas between the group and enhance communication skills. In addition, this study also identifies students motivation has increased as much more enthusiastic. The same approach goes to students' attitude and behavior on their learning by enjoying using the student-centered learning. Further research needed on the potential of student-centred learning approach to encourage students to build critical thinking, solve the problem creatively, share the idea between group members and enhance communication skills. Meanwhile, students' attitude and motivation levels to participate in student-centred learning activities do not related with gender. The implication of this study is that student-centred learning activity is designed to emphasis on attitude and motivation, as well as other skills enhancement without considering gender one of factor to achieve active participation and effective learning.

\section{Acknowledgments}

The authors would like to thank the Ministry of Higher Education, Malaysia, for supporting this research under the Research fund, E15501, Research Management Centre, UTHM and Geran Penyelidikan Pasca Siswazah (GPPS) VOT No H442.

\section{REFERENCES}

[1] Abdullah, M.H., Sham, F.M. \& Ismail, A. (2018). Pendekatan Motivasi Dalam Dakwah Remaja. Jurnal Hadhari, 10(1), 77-92. Retrieve from http://ejournal.ukm.my/jhadhari/article/view/25682/7880

[2] Abusama, M., Haming, M., Hamzah, M. N., \& R. (2017). Effect of motivation, competence and Islamic leadership on job satisfaction and Teacher performance in vocational high school. https://doi.org/10.31227/osf.io/r53qx

[3] Ahmad, Jalani and Hasmori. (2015). Tvet di Malaysia: Cabaran dan Harapan. Seminar Kebangsaan Majlis
Dekan-Dekan Pendidikan Awam. Retrieved from https://www.researchgate.net/publication/282855369_TEV T_di_Malaysia_Cabaran_dan_Harapan

[4] Al-Balushi, S.M., Ambusaidi, A.K., Al-Balushi, K.A., Al-Hajri, F., Al-Sinani, M.S., (2020). Student centred and teacher centred science classrooms as visualized by science teachers and their supervisors. Teacher and Teacher Education, 89 (March), doi.org/10.1016/j.tate.2019.103014

[5] Ali, S. (2019). Problem Based Learning: A Student-Centered Approach. English Language Teaching. 12. 73. 10.5539/elt.v12n5p73.

[6] Baeten, M., Kyndt, E., Struvyen, K., \& Dochy, F. (2013). Student-centred teaching methods: Can they optimise students' approaches to learning in professional higher education? Studies in Educational Evaluation, 39, 14-22.

[7] Basir, N.K., Hamzah, M.I. \& Abdul Razak, K. (2017). Sikap dalam Pembelajaran Berasaskan Projek Terhadap Pencapaian Pelajar di Politeknik Perak. Tinta Artikulasi Membina Ummah, 3(1), 1-14

[8] Chen, U.R., Masek, A. \& Amiruddin, M.H. (2014). Kajian Gaya Pembelajaran Dan Motivasi Terhadap Pencapaian Pelajar Diploma Kejuruteraan Di Politeknik. Prosiding CiE-TVET. Pp. 117-136.

[9] Fadzilah, A.H. (2017). Pelaksanaan Pengajaran Dan Pembelajaran Koperatif Berasaskan Abad Ke-21: Satu Tinjauan Di Sekolah Menengah Kebangsaan Pekan Nenas. Universiti Tun Hussein Onn Malaysia: Ijazah Sarjana Tesis.

[10] Hashim, S., Utami, P., Abdul Rahman, M. H., Jumaat, N. F., \& Eh Phon, \& D. N. (2019). Knowledge Construction Process in an Open Learning System among Technical and Vocational Education and Training (TVET) Practitioners. Journal of Technical Education and Training, 11(1). Retrieved fromhttps://publisher.uthm.edu.my/ojs/index.php /JTET/article/view/3066

[11] Hsia, L.H. \& Sung, H.Y. (2019). Effects of a mobile technology-supported peer assessment approach on students' learning motivation and perceptions in a college flipped dance class. International Journal of Mobile Learning and Organization, 14(1), doi.org/10.1504/IJMLO. 2020.103892

[12] Iberahim, Mahamod and Mohamad. (2017). Pembelajaran Abad Ke-21 Dan Pengaruhnya Terhadap Sikap, Motivasi Dan Pencapaian Bahasa Melayu Pelajar Sekolah Menengah. Jurnal Pendidikan Bahasa Melayu, 7(2), 77-88.

[13] Ibrahim, M.Z, Ab Rahman, M.Z \& M. Yasin (2012). Assessing Students Perceptions of Service Quality in Technical Educational and Vocational Training (TEVT) Institution in Malaysia. International Conference on Teaching and Learning in Higher Education (ICTLHE 2012) in conjunction with RCEE \& RHED 2012 https://doi.org/10.1016/j.sbspro.2012.09.655

[14] Ismail. (2015). Penguasaan Teknik Kemahiran Fasilitator Dalam Pelaksanaan Pembelajaran Berpusatkan Pelajar di Universiti Tun Hussein Onn Malaysia. Universiti Tun Hussein Onn Malaysia

[15] Ismail, S. dan Awang, M.I. (2004). Penilaian Terhadap Pelaksanaan Pembelajaran Kolaboratif Dalam Pengajaran Pendidikan Islam. 1-13. "Not Published" 
[16] Kornell, N., Bjork, R.A. (2007). The promise and perils of self-regulated study. Psychonomic Bulletin \& Review 14, 219-224. https://doi.org/10.3758/BF03194055

[17] Li, Yap. (2016). Transforming Conventional Teaching Classroom to Learner-Centred Teaching Classroom Using Multimedia-Mediated Learning Module. International Journal of Information and Education Technology. 6 . 105-112. 10.7763/IJIET.2016.V6.667.

[18] Masek, A (2016). An appropriate technique of facilitation using students' participation level measurement in the PBL environment. International jornal of engineering education, 32(1), pp 402-408.

[19] Mahamod, Zamri dan Lambri, Alizah (2015). Pengajaran dan Pembelajaran Bahasa Melayu Berpusatkan Pelajar di Institusi Pengajian Tinggi: Pelaksanaan dan Penerimaan Pelajar. Jurnal Personalia Pelajar, 18(1), 1-12.

[20] Murphy, P (2005). Learners, Learning and Assessment. Paul Chapman Publishing in association with The Open University. Pp 69-82.

[21] Nawi, Z.M. dan Hamzah, Z.A.Z. (2013). Sikap dan motivasi pelajar terhadap pembelajaran Bahasa Melayu. Social and Behavioral Sciences, 408-415

[22] Pavlova, M. \& Chen, C. S. (2019). Facilitating the development of students' generic green skills in TVET: An ESD pedagogical model. TVET@Asia, 12. Retrieved from http://www.tvet-online.asia/12/issues/issue12

[23] Pentawar, A. S., Swami, M. S. U., \& Dist-Beed, M. (2020) STUDENT CENTERED TEACHING AND EVALUATION METHODS IN SOCIAL SCIENCES

[24] Prayekti. (2016). Effects of Problem-Based Learning Model
Versus Expository Model and Motivation to Achieve for Student's Physic Learning Result of Senior High School at Class Xi. Journal of Education and Practice, 7(1), 30-37.

[25] Sardiman. (2008). Interaksi dan Motivasi Belajar-Mengajar. Jakarta: PT Raja Grafi ndo Persada.

[26] Somasundram, B. dan Mahamod, Z. (2017). Keberkesanan Pembelajaran Koperatif Terhadap Pencapaian Dan Motivasi Murid Sekolah Menengah Dalam Pembelajaran Bahasa Melayu. Jurnal Pendidikan Bahasa Melayu, 7(1), 11-23.

[27] Leatemia LD, Susilo AP, van Berkel H. Self-directed learning readiness of Asian students: Students' perspective on a hybrid problem based learning curriculum. Int J Med Educ. 2016;7:385-392. Published 2016 Dec 3. doi:10.5116/ijme.582e.021b

[28] Tasgin, A. and Coskun, G. (2018). The Relationship between Academic Motivations and Unviersity Student's Attitudes towards learning. International Journal of Instruction, 11(4), 935-950.

[29] Timbang, Mahamod, Yusoff dan Badushah. (2010). Masalah Membaca Murid-murid Sekolah Rendah Kerajaan di Brunei Darussalam: Satu Kajian Kes. Jurnal Pendidikan Malaysia, 35(2), 77-85.

[30] Ting, S., Marzuki, E., Chuah, K., Misieng, J., \& Jerome, C. (2017). EMPLOYERS' VIEWS ON IMPORTANCE OF ENGLISH PROFICIENCY AND COMMUNICATION SKILL FOR EMPLOYABILITY IN MALAYSIA. Indonesian Journal of Applied Linguistics, 7(2), 315-327. doi:https://doi.org/10.17509/ijal.v7i2.8132

[31] Yahaya, A., Hashim, S., Yahaya, N., Ramli, J. dan Bahuri, I.S. (2011). Tinjauan Amalan Pembelajaran Koperatif dalam Kalangan Pelajar Tingkatan Dua Maktab Rendah Sains Mara. Jurnal Penerbitan UTM, 1-18 